Jpn. J. Med. Mycol.

Vol. 35, 257-261, 1994

ISSN $0916-4804$

総説

Pneumocystis carinii と真菌の関連について

\author{
安岡彰 \\ 東京大学医科学研究所感染免疫内科
}

要旨

AIDS の日和見感染症として重要なカリニ肺炎の原因微生物であるPneumocystis carinii ( $P$. carinii）は, 遺伝子レベルの相同性から, 近年では真菌に近い生命体と考えられるようになってきて いる.われわれも，P. carinii と真菌に共通した現象を認めたのでここに報告した.

1. 真菌の細胞壁抢よび $P$. carinii の囊子壁には $(1 \rightarrow 3)-\beta$-D-glucan $(\beta$-glucan) が存在する が, 深在性真菌症の患者血清からこの $\beta$-glucan が検出され, 補助診断法として有用であると報告され ている. 我々はカリ二肺炎患者 5 名から $\beta$-glucan の検出を試み，うち 4 例で $300 \mathrm{pg} / \mathrm{m} l$ と明らかな上 昇を認め, 臨床経過を反映して消長が観察された。

2. 真菌抢よびP. carinii の外層は mannanに富んでいるが, この mannan と結合して抗真菌活 性を発揮する benanomicin A を, 実験的カリ二肺炎マウスに $100 \mathrm{mg} / \mathrm{kg} 3$ 週間投与し, 抗カリ二活 性を検討した，その結果, 肺切片でのP. carinii の囊子の数が, 対照マウスでは 1 視野中平均 206 個 認められたのに対し, benanomicin A 治療群では平均 4.9 個と明らかに改善が見られた.

以上, 真菌と共通の補助診断法の存在, 抗真菌剂による治療の可能性など, P. carinii に真菌との共 通部分が多いことを示した。

Key words : ニューモシスチスカリニ (Pneumocystis carinii) $（ 1 \rightarrow 3)-\beta$-D-グルカン $(1 \rightarrow$ 3)- $\beta$-D-glucan), ベナノマイシンA（Benanomicin A)，抗カリニ治療薬（antiP. carinii drug)

\section{はじめに}

カリニ肺炎は最も重要な AIDS の日和見感染症 である. AIDS が発見されることになった発端が, アメリカ都市部に抢けるカリニ肺炎の多発であっ たことは有名な事実であり ${ }^{1)}$, 現在も AIDS 患者 の予後を左右する疾患であることにかわりがない. Fig. 1 は当院における AIDS 発症疾患を示したも のであるが，やはりカリニ肺炎で発症する患者が 過半数を占めている.

カリニ肺炎はPneumocystis carinii ( P. carinii) による感染症であるが, この微生物に関しては未 だ不明の点が多い。その継代培養は未だ困難であ

別刷請求先 : 安岡 彰

₹ 108 東京都港区白金台 4-6-1

東京大学医科学研究所感染免疫内科
るし，ヒトの感染経路についても明らかでない. 分類学上の位置についても長い間, 原虫か真菌か で議論されてきていた．貪食性の欠如や囊子の形 態などでは真菌を示唆する結果が得られていたが, トロホゾイトの形態, 電顕所見, 治療に抗原虫薬 が有効であることなどから，原虫と考える意見が 優勢を占めていた。これに対して，近年の遺伝子 解析を用いた手法によりある方向性が示されるよ うになった. Edman ら²)は16S-ribosomal RNAを 解析してその相同性を比較し報告している. Ribosomal RNA は細胞に共通して存在し, 比較的離 れた種の間でも変異が少ないため, その塩基配列 を比較することにより遺伝子のレベルでの類縁を 検討するのに適している. $16 \mathrm{~S}$ ribosomal RNA からは, P. carinii は Saccharomycesなどの真菌 と近似しており，原虫とは隔たりがあったと述べ 


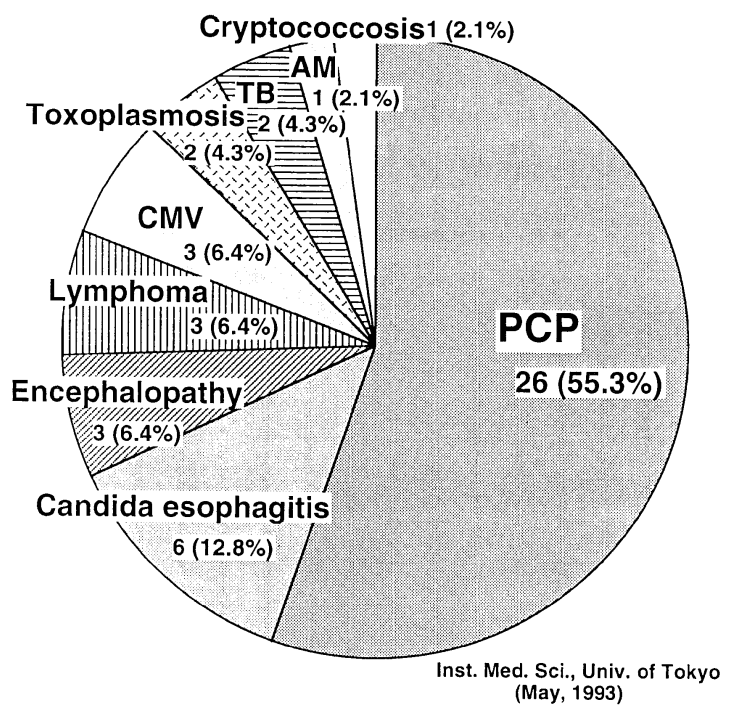

Fig. 1. Indicative diseases of AIDS in 47 infected-patients.

ている. 渡辺ら ${ }^{3)}$ は $5 \mathrm{~S}$ ribosomal RNAを解析 し，どちらかといえば真菌に近いことを報告して いる。

我々はAIDSに合併したカリ二肺炎患者の検討 などから，P. carinii と真菌との間に共通してみ られた現象を認めた。これらの結果もP. carinii が真菌に近いことの傍証となり得るものと考えら れた。

\section{1. カリニ肺炎患者からの $\beta$-glucan の検出}

$(1 \rightarrow 3)$ - $\beta$-D-glucan ( $\beta$-glucan) は, 真菌の細 胞壁成分として, 真菌に普遍的に認められること が知られている。 $\beta$-glucan は深在性真菌症の患 者の末梢血中から検出されることが知られるよう になり, 深在性真菌症の補助診断法としての有用 性が認められている4).

Gテスト（生化学工業）は, limulus test を応 用した特異的な $\beta$-glucan 検出キットである ${ }^{5)}$. Limulus test はカブトガニの血液の凝固系を利 用してエンドトキシンを検出しようとするもので, 当初から真菌血症の場合にも陽性化することが知 られていた。これはこの反応が，エンドトキシン だけでなく， $\beta$-glucanでも活性化されるためで ある。この反応系を glucanのみで反応するよう に改変したものが Gテストである.
一方, Matsumoto ら ${ }^{6)}$ は $P$. carinii の囊子壁に 真菌と共通の $\beta$-glucan が存在することを報告し ている.そこで我々は Gテストを用いて P. carinii およびカリ二肺炎患者血清から $\beta$-glucan が検出 されるか否かを検討した。

P. carinii 自体からの $\beta$-glucan の検出の検討は, カリニ感染ラットの肺胞洗浄液を用いた。ラット はヌードラットを用い，すでにカリニ肺炎に感染 しているラットとアイソレーター内で同居させる ことによりP. cariniiの感染を起こさせた7). 感 染および対照ラットを脱血死させた後，気管内へ PBS を注入回収し，最終回収量が $15 \mathrm{~m} l$ となるま で洗浄を繰り返した。

$\beta$-glucanの結果は, 非感染ラットでは $57 \mathrm{pg} /$ $\mathrm{m} l$ に対して, 感染ラットでは $10,000 \mathrm{pg} / \mathrm{ml}$ と, 明らかに $\beta$-glucan 值の上昇が観察された (Fig. 2). 今回の採取では環境中の $\beta$-glucan の混入が相当 程度考えられたため，コントロールでの上昇はこ の影響があると考えられ, 感染ラットの著しい上 昇は，P. carinii 由来と考えられた。すなわち，P. carinii の囊子壁の $\beta$-glucan は G テストで検出可 能と考えられた。

次に実際のカリ二肺炎患者の血清から, P. carinii 由来の $\beta$-glucan が検出されるか否かの検討を行っ た.

結果を Fig. 3 に示した. HIV 抗体陽性で，いず れの日和見感染症も見られなかった 15 例の患者 では血清中 $\beta$-glucan はすべて $10 \mathrm{pg} / \mathrm{m} l$ 以下であ り，Gテストの正常コントロールと同様であった． 当院でAIDS に合併し, 経皮肺吸引又は気管支肺 胞洗浄によってカリ二肺炎の確定診断が得られた 5 例の患者では, 最高 $1,135 \mathrm{pg} / \mathrm{m} l$ と, 対照と比べ て明らかに $\beta$-glucan 值が上昇していた。 5 例の うち 1 例のみで $9.0 \mathrm{pg} / \mathrm{m} l$ と上昇が見られなかっ たが，本例はカリ二肺炎の予防投薬中の発症例で あり，臨床的にはごく初期のカリ二肺炎であった。 他の 4 例ではいずれも $300 \mathrm{pg} / \mathrm{m} l$ 以上と明らかに 上昇しており，臨床経過を反映して増減が観察さ れた.これらの患者では口腔カンジダ症の合併例 があったが，明らかな深在性真菌症が疑われた症 例はなかった。

これらの結果から，P. cariniiの囊子壁には， 真菌の細胞壁と同様の $\beta$-glucan が存在し, 感染 者の血液中にも検出できることが明らかとなった. 


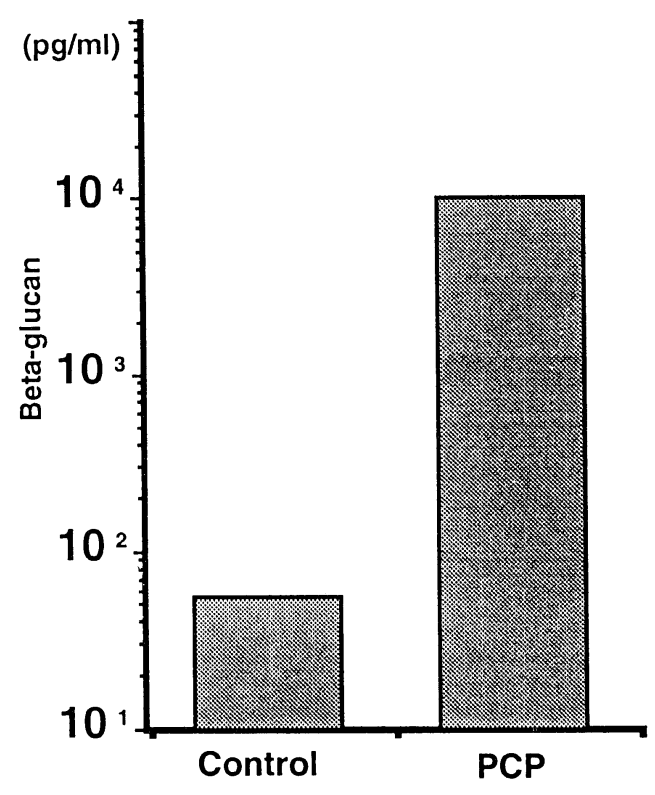

Fig. 2. Beta-glucan in BALF obtained from $P$. carinii infected rats.

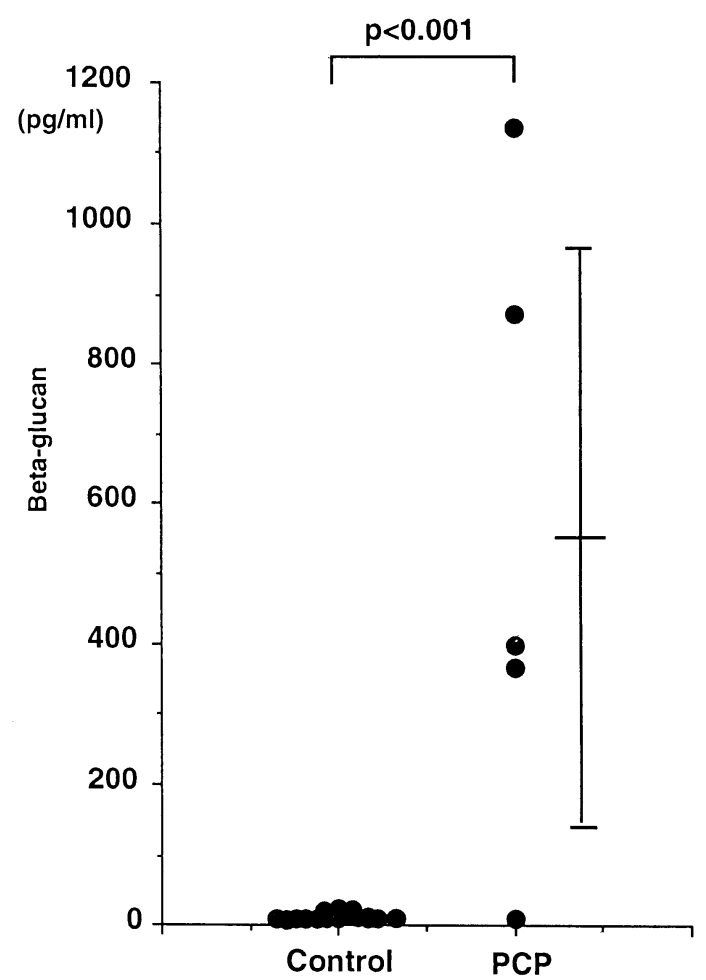

Fig. 3. Beta-glucan in patients with PCP.
このことは, P. carinii が真菌と共通の構造を有 していることを示しており，P. carinii と真菌の 類似性の一つの傍証となると思われた。ささに， 深在性真菌症の補助診断法のひとつが同様にカリ 二肺炎の補助診断法として役立つことを示した。 カリ二肺炎の診断にはPCR などの優れた方法が あるが7), 経過観察を繰り返し行える方法として $\beta$-glucan 測定が今後臨床的に有用な指標になる ものと思われる。

\section{2. 抗真菌剤の $P$. carinii に対する効果}

P. cariniiにも $\beta$-glucan が存在するというこ とから抗真菌剂のうち $\beta$-glucan 合成阻害剤の抗 カリニ活性の検討が行われ，ラットのカリニ肺炎 で効果が見られたとの報告がある．Echinocandin 系の L-671,329 と papulacandin 系の L-687,781 に ついての検討では, P. carinii 感染ラットに対し それぞれ $0.3 \mathrm{mg} / \mathrm{kg}, 5 \sim 10 \mathrm{mg} / \mathrm{kg}$ 連日の投与で 効果があったと報告されている8).

一方, 真菌の細胞壁の最外層は mannanに富ん だ構造であることが知られているが，P. carinii のトロホゾイトおよび囊子にも外層は mannan が 存在するとされている ${ }^{6)}$.このことから, mannan と結合して抗真菌活性がみられると考えられてい る新しい構造の抗真菌薬 benanomicin A (微生 物化学研究所, 明治製菓) ${ }^{9)}$ について, P. carinii に対する抗微生物活性の有無の検討を行った.

P. carinii は培養することは困難であるため, 実験方法として直接マウスを用いたin vivoの検 討を行った. BALB/c nu/nu 4 週齢メスマウスを, 既感染マウスと同居飼育することにより経気道感 染を成立させて使用した7). 同居開始後 12 週程で カリ二肺炎が発症したが，薬剤投与開始は同居開 始後 20 週とした。治療群は 4 匹で, benanomicin A $100 \mathrm{mg} /$ day 3 週間腹腔内投与し, 生理食塩 水を投与したコントロール群（3匹）と比較を行っ た. 投与前後での体重変化, 投与後の肺重量, お よび肺切片でのP. cariniiの囊子数を比較検討し た. P. cariniiの囊子数の計数は, 両肺の薄切切 片をグロコット染色したものを顕微鏡で 200 倍で 観察を行い，1視野中にみられる囊子の数を肉眼 的にカウントし, 1 個体 6 視野の平均を求めた.

結果は, 体重変化は治療前平均が $16.5 \mathrm{~g}$ であっ たが, コントロール群は平均 $14.3 \mathrm{~g}$ と減少傾向に 


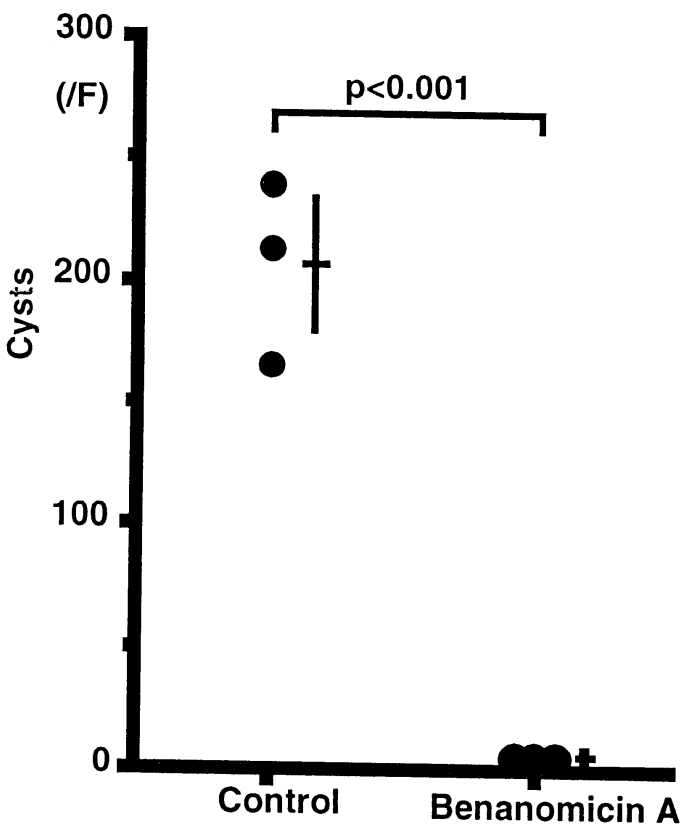

Fig. 4. Number of $P$. carinii cysts after treatment with or without benanomicin A.

あり, 治療群は $18.0 \mathrm{~g}$ と増加がみられた。また肉 眼的にも治療群はチアノーゼが消失し正常マウス に近い外観となっていたのに対し，コントロール 群はチアノーゼが強く, 多呼吸を呈していた。肺 重量は, コントロール群は平均 $0.331 \mathrm{~g}$ と炎症反 応と滲出液によると思われる重量増加が見られた が, 治療群では $0.240 \mathrm{~g}$ と有意に軽く, 充分な含気 が認められた. 肺切片の囊子数の結果は Fig. 4 に 示した. コントロール群では 1 視野平均 206 個の 囊子が認められたのに対し, benanomicin A 治療 群では 1 視野中 4.9 個と有意に減少しており，か なりの視野では明らかな霊子は見られなくなって いた. 以上の結果から, benanomicin Aには抗力 リニ活性が認められることが明らかとなった。

\section{結語}

これらの結果から, 真菌群と P. cariniiにはか なりの共通事項があることが明らかとなった。最 近では新しい知見を踏まえて $P$. carinii 真菌と する考え方が広がっているが，遺伝子解析を直ち に分類学的に用いて P. carinii を真菌と断じるこ とには批判の意見もある ${ }^{10)}$. 今後も様々なデー夕 の集積と研究の発展が望まれる.

\section{文献}

1) Gottlieb MS, Schroff R, Schanker HM, Weisman JD, Fan PT, Wolf RA, Saxon A : Pneumocystis carinii pneumonia and mucosal candidiasis in previously healthy homosexual men. N Engl J Med 305 : 1425 $-1431,1981$.

2) Edman JC, Kovacs JA, Masur H, Santi DV, Elwood HJ, Sogin ML: Ribosomal RNA sequence shows Pneumocystis carinii to be a member of the fungi. Nature 334 : 519-522, 1988.

3) Watanabe J, Hori H, Tanabe K, Nakamura $\mathrm{Y}$ : Phylogenetic association of Pneumocystis carinii with the 'Rhizopoda/Myxomycota/Zygomycota group' indicated by comparison of $5 \mathrm{~S}$ ribosomal RNA sequences. Molecular and biochemical parasitology 32 : 163-168, 1989.

4) Kohno S, Mitsutake K, Maesaki S, Yasuoka A, Miyazaki T, Kaku M, Koga H, Hara K: An evaluation of serodiagnostic tests in patients with candidemia: Betaglucan, mannan, candida antigen by CandTec and D-arabinitol. Microbiol Immunol 37: 207-212, 1993.

5) Obayashi T, Yoshida M, Tamura H, Aketagawa J, Tanaka S, Kawai T : Determination of plasma $(1 \rightarrow 3)-\beta-D$-glucan: A new diagnostic aid to deep mycosis. $J$ Med Vet Mycol $30:$ 275-280, 1992.

6) Matsumoto $Y$, Matsuda $S$, Tegoshi $T$ : Yeast glucan in the cyst wall of Pneumocystis carinii. J Protozool 36 : 21 S-22 S, 1989.

7) Kitada K, Oka S, Kimura S, Shimada K, Serikawa T, Yamada J, Tsunoo H, Egawa K, Nakamura Y:Detection of Pneumocystis carinii sequences by polymerase chain reaction: Animal models and clinical application. J Clin Microbiol 29 : 1985-1990, 1991.

8) Schmats DM, Romancheck MA, Pittarelli LA, Schwarts RE, Fromtling RA, Nollstadt $\mathrm{KH}$, Vonmiddlesworth FL, Wilson KE, Turner MJ : Treatment of Pneumocystis carinii pneumonia with $1,3 \beta$-glucan synthesis inhibitors. Proc Natl Acad Sci 87 : 5950-5954, 1990.

9) Takeuchi T, Hara T, Naganawa H, Okada M, Hamada M, Umezawa H, Gomi S, Sezaki M, Kondo S: New antifungal anti- 
biotics, benanomicins $\mathrm{A}$ and $\mathrm{B}$ from an Actinomycete. J Antibotics 41:807-811, 1988.
10）吉田幸雄: Pneumocystis carinii の生活環 原虫か真菌か一。臨床と微生物 $20: 901-906$, 1993.

\title{
Relation between Pneumocystis carinii and Fungi
}

\author{
Akira Yasuoka \\ Department of Infectious Diseases and Applied Immunology, \\ the Institute of Medical Science, the University of Tokyo
}

Pneumocystis carinii ( $P$. carinii), which is one of the major pathogens in AIDS patients, is considered a fungus from results of molecular biological analysis. We made a couple of interesting observations concerned with the cross relationship between $P$. carinii and fungi.

First, we detected $(1 \rightarrow 3)$-beta-D-glucan (beta-glucan) in sera obtained from patients with $P$. carinii pneumonia: Beta-glucan is one of the major components of the cyst wall of $P$. carinii as well as the cell wall of fungi. There are several reports of beta-glucan being detected in sera obtained from patients with deep-seated mycosis. In four of the five $P$. carinii pneumonia patients, the level of beta-glucan was elevated more than $300 \mathrm{pg} / \mathrm{m} l$ in their sera, and the level decreased along with clinical improvement.

Second, we found a new anti-P. carinii agent which was under development as an anti-fungal drug: The cell wall of $P$. carinii and fungi have a similar structure with a great deal of mannan backbone. Benanomicin A has antimycotic activity by binding to mannan. We examined the antipneumocystis activity of benanomicin A using mice with $P$. carinii pneumonia. After completion of three weeks of treatment with or without $100 \mathrm{mg} / \mathrm{kg}$ of benanomicin A, the mean number of cysts by high performance microscopic field in the lung was 4.9 in the treated group, and 206 in the control group. There was thus a statistical difference between the two. The result indicated that the agent had the potential to be a new anti- $P$. carinii drug with a new mechanism of anti$P$. carinii action. 